nom smislu. Nadalje, udžbenik pruža solidnu teorijsku pozadinu koja je upotpunjena aktualnim podacima o trendu kretanja socioekonomskih varijabli, što tekst u konačnici čini gotovo dominantnim izvorom objektivnih informacija o ekonomiji EU-a i perspektivi života u zajednici u kojoj se nacionalni identitet i suverenitet poistovjećuju s nadnacionalnim identitetom i pripadnošću uniji. Donoseći pregled teoretskih stavova koji se bave ovom problematikom, ali i niz zanimljivih argumenata, spoznaja i zaključaka, udžbenik pobuđuje znatiželju i čita se s uživanjem. Zato ga toplo preporučujem svima koji žele proširiti vidokrug i znanje o funkcioniranju EU-a.

Daniel Tomić

\section{doi:10.5559/di.21.3.13 \\ Geran-Marko Miletić U POTrAzI ZA DRUGIM PROSTOROM Sociologijski aspekti sekundarnog stanovanja U Hrvatskoj}

Institut društvenih znanosti Ivo Pilar, Zagreb, $2011 ., 292$ str.

U izdanju Instituta društvenih znanosti "Ivo Pilar", biblioteke Centra za urbane i ruralne studije, objavljena je knjiga Gerana-Marka Miletića U potrazi za drugim prostorom: sociologijski aspekti sekundarnog stanovanja u Hrvatskoj. Knjiga ima 292 stranice, sastoji se od uvoda, pet osnovnih poglavlja, unutar kojih je više potpoglavlja i podcjelina, zaključnog razmatranja te po- sebnih priloga s brojnim tablicama na kraju knjige. Glavna su poglavlja: 1. Uvod, 2. Teorijski okvir za analizu sekundarnog stanovanja, 3. Obrasci korištenja stanova za odmor, 4. Evolucija sekundarnog stanovanja u Hrvatskoj, 5. Anketno istraživanje - Zagrepčani u potrazi za "drugim prostorima", 6. Zaključne napomene i 7. Prilog.

U prvom, uvodnom, poglavlju autor najprije obrazlaže sam pojam sekundarno stanovanje, polazeći od termina stanovi za odmor, koji se, prema definiciji Državnog zavoda za statistiku, isključivo rabe za odmor i rekreaciju - bilo povremeno ili više mjeseci u godini. Budući da je najveća gustoća sekundarnih stanova na hrvatskom priobalju, za koje Miletić drži kako je danas zasigurno najvredniji nacionalni resurs, razvoj sekundarnoga stanovanja stvara i određene socijalne, ekonomske i prostorne promjene, a siguran je i nastavak rasta broja stambenih objekata namijenjenih odmoru u Hrvatskoj. Samim time intenzivirat će se i navedene promjene, pa autor zaključuje kako širenje sekundarnih stanova postaje jedna od važnijih tema u promišljanju daljnjeg razvoja Hrvatske. Stoga je i jedan od glavnih ciljeva ove analize i istraživanja, pokušati odgovoriti na dva temeljna pitanja o naznačenoj pojavi: prvo je pitanje o ishodištima i implikacijama širenja sekundarnoga stanovanja u Republici Hrvatskoj, a drugo je o prirodi takva stanovanja na više adresa.

Drugo poglavlje, Teorijski okvir za analizu sekundarnog stanovanja, podijeljeno je na tri potpoglavlja: Stanovanje $i$ dihotomija primarno/sekundarno, Sličnosti i razlike između turizma i sekundarnog stanovanja, Skica za hipotetski model sekundarnog stanovanja. U prvom potpoglavlju autor razmatra osnovne pristupe $\mathrm{u}$ razumijevanju stambene problematike i analizira pitanje kada stanovanje prestaje biti primarno i postaje sekundarno. Polazeći od činjenice kako je (primarno) stanovanje jedna od temeljnih antropoloških kategorija kroz koju se na određen način odražava ljudska težnja za stvaranjem zavičaja, ali i potreba za individualizacijom, autor ističe kako vlastiti stam- 
beni prostor ima važnu ulogu u rutiniziranju svakodnevice te u stvaranju osjećaja pouzdanja i sigurnosti, bez čega bi pojedinac bio neadekvatno opremljen za bivanje-u-svijetu. Ta psihološka, ali i socijalna, uloga stana i stanovanja postaje još važnija s ubrzavanjem transformacijskih procesa kroz koje suvremeno društvo prolazi. U sljedećem se osvrće na bitne odlike turističkoga djelovanja i promišlja značenje te nove druge adrese, za koju se pita nije li zapravo riječ o (novoj) zavičajnosti, a ne tek o pukom doživljaju. Turizam prije svega podrazumijeva ograničen prekid s uspostavljenom rutinom i praksom, prekid koji pojedincu dopušta da se upusti u aktivnosti koje su mu uskraćene u njegovoj svakodnevici; da se upusti u potragu za iskustvima i doživljajima koji se ne susreću u uobičajenom, normalnom životnom okruženju. U tom smislu turizam, odnosno turističko djelovanje, na određen način odražava čežnju za ekstravagancijom, prekomjernošću i uzbuđenjem. Stoga, zaključuje Miletić riječ je o praksi kojoj je ishodište često hedonizam i u kojoj se kompleksnost života i svakodnevica reduciraju samo na užitak. Shvaćajući (primarno) stanovanje i turizam na ovaj način te imajući pred očima osnovno obilježje sekundarnoga stanovanja, autor smatra kako je sekundarno stanovanje karakterom svoje izvedbe ipak nešto bliže primarnom stanovanju nego turističkom djelovanju: turizam teži ekstraordinarnosti, a stanovanje na dvije adrese refleksija je nešto drukčije potrage za "drugim prostorom". Dakle, sekundarni je stan označen kao rezervni položaj, koji - udomljujući njegovo kućanstvo - pojedincu pomaže uspostaviti funkcionalnu ravnotežu koja mu olakšava bivanje-u-svijetu. U zadnjem potpoglavlju Miletić predlaže skicu za hipotet- ski model sekundarnoga stanovanja, najprije definirajući formu, sadržaj i funkciju sekundarnoga stanovanja te na kraju postavlja pitanje koje nas vodi prema glavnoj hipotezi: jesu li sekundarni stanovi foucaultovski rečeno protumjesta, odnosno je li sekundarno stanovanje zapravo heterotopično djelovanje izraslo iz potrage za kompenzacijom?

U trećem poglavlju pod naslovom Obrasci korištenja stanova za odmor Miletić najprije daje nekoliko napomena o pretpovijesti stanovanja na više adresa, ističući kako porast broja sekundarnih stanova potiče društvena transformacija i stvaranje fleksibilnijih radnih mjesta, ekonomski razvitak i rast prihoda kućanstva, ali i razvoj tehnologije i povećana mobilnost. Nadalje naglašava kako se povećano zanimanje za sekundarno stanovanje ne može odvojiti i od nekih demografskih procesa, poput starenja stanovništva te depopulacije ruralnih sredina. Istaknuti su još neki od čimbenika koji na određen način pridonose rastu interesa za sekundarno stanovanje, a to su klimatske promjene i konzumeristički mentalitet suvremenoga društva. Ukupnost ovih momenata i silnica stvara okruženje u kojem posjedovati alternativnu adresu postaje normalno, a - što je još važnije - i dostupno prosječnom kućanstvu, zaključuje Miletić. Potom autor analizira primjere pojavnosti sekundarnoga stanovanja iz raznih dijelova svijeta, prikazujući najprije iskustva s drugih kontinenata te praksu u europskom okruženju. Prikazani su podaci za SAD, Kanadu, Novi Zeland, Rusiju, Španjolsku, Grčku, Švedsku i Dansku, a ti primjeri širenja sekundarnoga stanovanja u nekoliko država otkrili su kako su stambeni objekti koji se rabe isključivo za odmor i rekreaciju međusobno vrlo različiti, po veličini i po opremljenosti, odnosno udobnosti. Sekundarni je stan i raskošna vila na Azurnoj obali, ali i supstandardni novozelandski crib nastao u domaćoj radinosti. Primjeri koje Miletić navodi kako bi opisao evoluciju sekundarnoga stanovanja u inozemstvu svjedoče kako slučajeva poput novozeland- 
skoga ima znatno više, o čemu govore primjeri u Rusiji, ali i stanovi za odmor nastali u grčkom kaosu. Uz skandinavske primjere stanova za odmor, ambicije kojih su uglavnom minimalističke, postaje jasno da suvremeno sekundarno stanovanje nikako nije povlastica samo najbogatijih. Iako su sekundarnom stanovanju češće sklona imućnija kućanstva, najviše stanova za odmor nalazi se u posjedu dijela društva koji se može okarakterizirati kao srednji sloj.

Posebno potpoglavlje autor posvećuje temeljnim karakteristikama procesa širenja sekundarnoga stanovanja i postavlja općenito pitanje zašto uopće imati stan za odmor te razmatra kako je sekundarno stanovanje istodobno čimbenik gospodarskih prostornih i socijalnih promjena. Spominjući obilježja sekundarnoga stanovanja, Miletić najprije pokazuje specifičnosti mjesta gdje se sekundarni stan realizira. Osim urbano-ruralnoga smjera, koji se pokazao kao dominantan obrazac za sekundarno stanovanje, analiza stranih iskustava pokazala je kako je smještanje sekundarnih stanova pod utjecajem još nekih čimbenika. Jedan od njih je, kaže Miletić, ambijentalna kakvoća lokacije, odnosno količina ugodnosti kojom neka sredina obiluje. Riječ je prije svega o kvalitetama određenoga krajolika, pri čemu su privlačnije lokacije u blizini mora, rijeke, jezera, planine ili nekih drugih privlačnih sadržaja, poput toplica, zabavnih parkova ili kulturno-povijesnih znamenitosti. Pristupačnost odredišta pokazala se kao jedan od važnijih čimbenika u odabiru prostora sekundarnoga stana, no ta se pristupačnost sve manje mjeri kroz prostornu udaljenost između prve i druge adrese, a sve više kroz udaljenost druge adrese od transportnih koridora i čvorišta (autocesta, luka, aerodroma). Ipak, bez obzira na naznačenu promjenu trenda, autor napominje kako su mnogi sekundarni stanovi i nadalje grupirani oko urbanih središta, koja su ujedno i najvažnija emitivna područja. Važan čimbenik koji autor ističe jest i zavičajni karakter same lokacije: sekundarni se stanovi ponekad smještaju u mjesta koja su povezana s djetinjstvom ili obiteljskim podrijetlom, što nerijetko uključuje i emocionalnu dimenziju takva odabira. Osvrćući se na strana iskustva sa sekundarnim stanovanjem, Miletić skreće pozornost i na pojavnost koja bi ubuduće mogla znatnije utjecati na stanje u Hrvatskoj. Riječ je o internacionalizaciji sekundarnoga stanovanja, odnosno o porastu zanimanja za posjedovanje drugoga stana $u$ inozemstvu. Primjeri koji su izdvojeni pokazuju kako je taj trend najprisutniji u Europi, a razloge treba tražiti u integracijskim procesima kojima se građanima Europske unije olakšava stjecanja nekretnina u državama članicama. U Hrvatskoj spomenuti trend ipak još nije znatnije prisutan. Kod nas je i nadalje najveći dio sekundarnih stanova domaćih ruku djelo, zaključuje Miletić, i nalazi se još uvijek u domaćim rukama.

Četvrto je poglavlje usredotočeno na evoluciju sekundarnoga stanovanja u Hrvatskoj. Najprije je prikazana kratka povijest prisutnosti stanova za odmor $\mathrm{u}$ Hrvatskoj, od skromnih početaka prije II. svjetskog rata, potom kroz prva desetljeća socijalizma, u kojima se očitovala društvena nepoželjnost stanova za odmor, zatim u razdoblju ekspanzije sekundarnoga stanovanja od 1971. do 1991. godine i na kraju na prijelazu iz 20. u 21. stoljeće. U drugom su dijelu ovoga poglavlja prikazane osnovne značajke te prostorni razmještaj stanova za odmor u Hrvatskoj prema Popisu iz 2001. godine prema kategorijama opremljenost $i$ karakteristike stanova za odmor i razmještaj stanova za odmor. U sljedećem potpoglavlju Miletić analizira koristi i štete od širenja sekundarnoga stanovanja u Hrvatskoj, a u zadnjem definira aktere i njihovu motivaciju za sekundarno stanovanje $\mathrm{u} \mathrm{Hr}$ vatskoj.

Peto poglavlje donosi rezultate istraživanja o Zagrepčanima u potrazi za "dru- 
gim prostorima". Rezultati i interpretacija podijeljeni su u četiri dijela i sadrže 39 tablica i 50 slika: najprije su prikazana osnovna obilježja sekundarnih stanova, potom struktura vlasnika, tj. odgovor na pitanje tko ima sekundarne stanove, zatim motivacija, odnosno razlozi posjedovanja sekundarnoga stana, i na kraju pozadina lociranja sekundarnih stanova. Ukratko, budući da Državni zavod za statistiku stanove za odmor u svojoj evidenciji ima tek od 1971. godine, od tada do zadnjega popisa stanovništva, kućanstava i stanova iz 2001. godine, kada ih je zabilježeno 182513 , njihov je broj gotovo 8 puta veći, odnosno porastao je za 795,4\%, dok, ističe Miletić, u istom razdoblju ukupan stambeni fond porastao je za "samo" 54\%. Statistički podaci pokazuju kako se najveći rast broja stanova za odmor dogodio sedamdesetih i osamdesetih godina 20. stoljeća, a devedesetih je usporen trend rasta. Autor misli kako je toliki porast između 1971. i 1991. godine teško objasniti isključivo naglim oslobađanjem individualnih aspiracija za odmorom i razonodom, nego ga treba tražiti i u potpori vladajućih struktura i na najvišoj razini i na lokalnoj razini kroz monetarno-ekonomsku i prostorno-plansku politiku. Kod monetarno-ekonomske politike radilo se o poticanju stanogradnje povoljnim kreditima, koji su se, iako namijenjeni isključivo rješavanju stambenoga pitanja, često rabili i za gradnju stanova za odmor, dok se kod prostorno-planske politike manje radilo o poticajnim mjerama, a više o izbjegavanju sankcija za kršenje graditeljskih normi, zaključuje autor.

U zaključnom razmatranju Miletić zbraja glavne rezultate analizom karakteristika samih stambenih objekata, koji se povremeno rabe isključivo za odmor i rekreaciju, razmatrajući pitanje tko, kako i zašto ima dvije adrese, od kojih jednu rabi za odmor i rekreaciju. Između ostalog, istraživanje je pokazalo kako znatan udio uzorkom obuhvaćenih kućanstava ima alternativnu adresu, čak svako četvrto kućanstvo u Zagrebu ima sekundarni stan ili drugi dom koji povremeno rabi isključivo kao mjesto za rekreaciju i odmor. Stoga autor zaključuje da su Zagrepčani poprilično zainteresirani za druge prostore, no ipak manji dio njih teži trajnom preseljenju. Iako popisni pokazatelji govore da je u zadnjem ratnom i tranzicijskom desetljeću prošloga stoljeća znatnije usporen rast broja stanova za odmor u Hrvatskoj, Miletićev empirijski uvid pokazuje kako se ipak ne može govoriti o smanjenju interesa hrvatskih građana za sekundarno stanovanje, nego prije o vlasničkom preslagivanju postojećih objekata u 1990-im godinama. Jedan od važnijih uvida jest $\mathrm{i}$ taj da je sekundarno stanovanje u Hrvatskoj važan čimbenik koloniziranja novoga, dotad uglavnom netaknutog, prostora, što ne znači da ono pridonosi ruralnoj revitalizaciji, nego samo da je ta revitalizacija povezana sa značajnom transformacijom krajolika. Usporedbom prosječne veličine sekundarnoga i primarnoga stana pokazalo se da su hrvatski sekundarni stanovi znatno skromniji u izvedbi od onih primarnih, a na razini stambenih uvjeta stanovi namijenjeni odmoru znatno su lošije opremljeni pomoćnim prostorijama i infrastrukturnim priključcima. S obzirom na prostornu distribuciju, u sedam jadranskih županija nalazi se oko dvije trećine svih hrvatskih sekundarnih stanova uglavnom izvan većih gradova, a gotovo trećina u okolici Zagreba, pa Miletić zaključuje kako bi se smještaj sekundarnih stanova u Hrvatskoj mogao opisati kao potraga za selom blizu mora ili selom blizu Zagreba. To pak dovodi do zaključka kako je udaljenost od većih urbanih cjelina ujedno i bijeg od naselja koja nisu privlačna ni za stalno stanovanje, na što upućuje i podatak kako je Idiličan krajolik prvi na popisu čimbenika koji utječu na odabir lokacije za sekundarni stan, dok najmanji utjecaj u toj odluci imaju želje lokalne zajednice ili 
očekivani porast cijena nekretnina na nekome mjestu. Zanimljiv je i podatak kako je nasljeđivanje sve češći način stjecanja sekundarnoga stana. Od glavnih nalaza, možda još za ovaj prikaz treba spomenuti kako se ekonomski i stambeni status kućanstava mogu povezati s odlukom o stanovanju na dvije adrese te da upotreba sekundarnih stanova ima sezonski karakter, jer je istraživanje pokazalo kako se sekundarni stanovi u prosjeku rabe oko dva i pol mjeseca (75 dana) u godini, i to uglavnom ljeti. Također se pokazalo kako je posjedovati kuću za odmor i statusni simbol i dio mita o društvenom napretku. Miletić ističe kako se ovdje nije radilo toliko o motivaciji koja u stanovima za odmor vidi isključivo oblik statusne legitimacije, koliko o tome da je nekima posjedovanje stana za odmor postalo normalno stanje - i zbog ekonomske snage kućanstva i zbog stila života što ga ti korisnici prakticiraju, pa se sekundarni stan zapravo doživljava kao dio standardne opreme imućnijega kućanstva.

Na kraju može se reći, kao što i sam autor zaključuje, kako je ovo istraživanje prikazalo relativno detaljnu sliku evolucije sekundarnoga stanovanja u Hrvatskoj, osobito kada je riječ o razmjerima i načinu na koji je taj fenomen prisutan u hrvatskom prostoru i u hrvatskom društvu, pa nam otkriva ponešto i o obilježjima te multilokalne prakse. Iako Miletić, i u teorijskom i u empirijskom dijelu, sustavno ulazi u problematiku vezanu uz sekundarno stanovanje u Hrvatskoj, sve aspekte nije bilo moguće sagledati, osobito one vezane uz ekološku i socijalnu problematiku, što ih sekundarno stanovanje ostavlja za sobom u sredinama u kojima je intenzivnije prisutno. To bi bile prije svega analize koje bi se s problematikom sekun- darnoga stanovanja trebale pozabaviti na samoj lokalnoj mikrorazini. U tom smislu ova je knjiga Gerana-Marka Miletića važan doprinos, jer daje fundamentalne uvide, temeljni okvir i polazišnu osnovu te smjernice ne samo za sva daljnja istraživanja u toj tematici nego i za prostorna planiranja i strategije razvoja mikroregija.

Krešimir Peračković

doi:10.5559/di.21.3.14

\section{Nena Rončević i Branko Rafajac PROMJENE U AKADEMSKOJ PROFESIJI: KOMPARATIVNA ANALIza}

Filozofski fakultet u Rijeci, Rijeka, 2010., 116 str.

Promjene u akademskoj profesiji: komparativna analiza - knjiga je nastala u okviru međunarodnoga kolaborativnog projekta "Akademska profesija u Europi: odgovori na izazove društva", u kojem sudjeluje i Hrvatska s projektom "Akademska profesija i društvena očekivanja: izazovi civilne misije sveučilišta". Knjiga je rezultat istraživačkog rada autora i članova projektnoga tima - Nene Rončević i Branka Rafajca. Utemeljenje istraživačkog rada autori pronalaze $\mathrm{u}$ rezultatima istraživanja "Promjene $\mathrm{u}$ akademskoj profesiji" (Changing Academic Profession, 2005-2007) (u daljnjem tekstu: (AP), koje je do danas provedeno $u$ više od 22 zemlje na svim kontinentima.

Izostanak zamjetnijeg interesa za područje akademske profesije u hrvatskoj istraživačkoj zajednici dalo je autorima dodatni poticaj za nastanak ove knjige. Tri poglavlja knjige - uz uvod, zaključak i popis literature - predstavljaju zaokruženu cjelinu te čitatelju nude uvid $u$ recentne spoznaje o ovoj temi. 